\title{
Pollen Morphology and Sucrose Giving on Stigma Relation with Incompatibility of Sweetpotato [Ipomoea batatas (L.) L.]
}

\author{
Febri Adi Susantoํ, Eko Sri Sulasmi ${ }^{1}$, St. A. Rahayuningish ${ }^{2}$ \\ ${ }^{1}$ Biology Department, Faculty of Mathematics and Natural Sciences, State University of Malang \\ ${ }^{2}$ Research Staff of Indonesian Legumes and Tuber Crops Research Institute, Kendalpayak St. Km 8, Malang, Indonesia
}

\section{ABSTRACT}

This research aimed to increase the success rate of self-pollination in sweetpotato through sucrose treatment on stigma and pollen nuclei check. Various concentration of sucrose was applied on the stigma. Prior to the crosses, the stigma was excised and lubricated with sucrose. Pedicel was lubricated with $100 \mathrm{ppm}$ of 2,4 D in lanolin. The result showed that the stigma of both varieties was longer than the anther. Papua Solosa showed $94,7 \%$ anther dehiscence and $70,25 \%$ pollen viability; whereas MSU 03028-10 showed 87, 3\% anther dehiscence and 87, 84\% pollen viability. Both of these varieties showed receptive stigma. Sucrose level in compatible pollination was lower than in incompatible pollination. Sugar in $50 \mathrm{ppm}$ concentration can increase the formation of fruit in self-pollination of Papua Solosa varieties from $0 \%$ to $70 \%$; $0 \%$ to $60 \%$ in self-pollination of MSU $03028-10$; and $10 \%$ to $90 \%$ of Papua Solosa $><$ MSU 03028-10. The pollen nuclei of both of varieties were trinucleate. Sweetpotato incompatibility system was sporophytic self-incompatibility type that can be fixed by sucrose treatment using $50 \mathrm{ppm}$ concentration, stigma excision, and $100 \mathrm{ppm}$ of 2,4D in lanolin.

Keywords: pollen morphology, sucrose giving, incompatibility of sweet potato

\section{INTRODUCTION}

The limited varieties of sweet potato (Ipomoea batatas L.) have been a problem that needs to be solved by the farmer. The efforts in breeding program for producing new varieties still continue. However incompatibility system of sweet potato may resist any plant breeding effort because it isn't followed by sexual embryo formation to produce new variety $[9,11]$. Incompatibility system is controlled by single $\mathrm{S}$ gene locus with multiple alleles [8]. Incompatibility mechanism related to the type of pollen has been resulted in plants [2]. According to the pollen nuclei, Convolvulaceae family has binucleate and trinucleate type of pollen. Gemetophytic self incompatibility was observed in binucleate

\section{${ }^{*}$ Corresponding author:}

Febri Adi Susanto

Biology Department, Faculty of Mathematics and Natural

Sciences, State University of Malang

Email: susantofebri27@gmail.com species using site of inhibition in pollen tube growth. Sporophytic self-incompatibilty was occurred in trinucleate species using site of inhibition of early pollen tube growth [2].

One of efforts which is aimed to increase the possibility to conduct plant crossbreeding to obtain new varieties is addition of an essential substance that may unavailable in sweet potato incompatibility $[3,5,10]$. Sucrose is an essential substance that seemed to be the key of successful germination and growth of in vivo pollen. Treatment of sucrose on sweet potato's stigma is expected to initiate the germination and penetration of pollen tube when incompatibility occurs; thus, fertilization can be preceded. The result of this research was assumed to increase the success rate of cross-pollination.

\section{MATERIALS AND METHODS}

Quantitative descriptive researches on flower biology observe the number of pollen nuclei, distance between anther and stigma, pollen 
viability, and measurement of pistil's sucrose concentration. The crossbreeding of sweet potato was conducted using straw technique. Flower emasculated at evening and crossed in the morning. Before crosses conducted, stigma were excised and lubricated with various sucrose concentration $(0 \mathrm{ppm}, 50 \mathrm{ppm}, 100 \mathrm{ppm}$, and 150 ppm) while the pedicel was lubricated with $2,4 \mathrm{D}$ in lanolin. Parameters measured were percentage of $(\%)$ fruit set from each treatment. Each treatment performed to 10 flowers that replicated in 3 times. Papua solosa varieties and MSU 03028-10 are selected to be the parental of this re-search. The type of cross were Papua solosa, MSU 03028-10, and Papua solosa $><$ MSU 03028-10.

Preliminary study was conducted to know the incompatibility degree of sweet potato. Acetolysis method [4] was used to observe the pollen nuclei; fluorescence method staining using aniline blue was used to determine the viability of pollen; and pistil receptivity was observed by Olympus microscope FSX 100. Acetocarmine was chosen as a comparison method to determine the viability of pollen. Pistil sucrose levels were measured with spectrophotometer UV-Vis
Varian/Cary 50 (each measurement used 30 pistils). Pollen were germinated in vitro in Bhojwani and Bhatnagar solid and liquid (100 g sucrose, $10 \mathrm{mg}$ boric acid, $30 \mathrm{mg}$ calcium nitrate, 20 $\mathrm{mg}$ magnesium sulphat, and $10 \mathrm{mg}$ potassium nitrate in $100 \mathrm{ml}$ distilled water, solid medium were added by $1 \%$ agar); modified Bhojwani and Bhatnagar (25 g sucrose, 0,005 mg boric acid, 500 $\mathrm{ml}$ distilled water); and Murashige and Skoog to know the germination degree of viable pollen.

\section{RESULTS AND DISCUSSION}

Both varieties showed self-incompatibility and cross compatibility bacause there was no fruit generated (Figure 1b) and/or only $10 \%$ fruit emerged (Figure 1a). Pollen viability of both varieties that had range $70,25 \%-91,52 \%$ could support fertilization. Based on the flower morphology, the distance between anther and stigma of both varieties was slightly exerted type where stigma was higher than highest anther with relative distance $5,12 \mathrm{~mm}$ in MSU 03028-10 and 4, $90 \mathrm{~mm}$ in Papua solosa (Figure 1d).

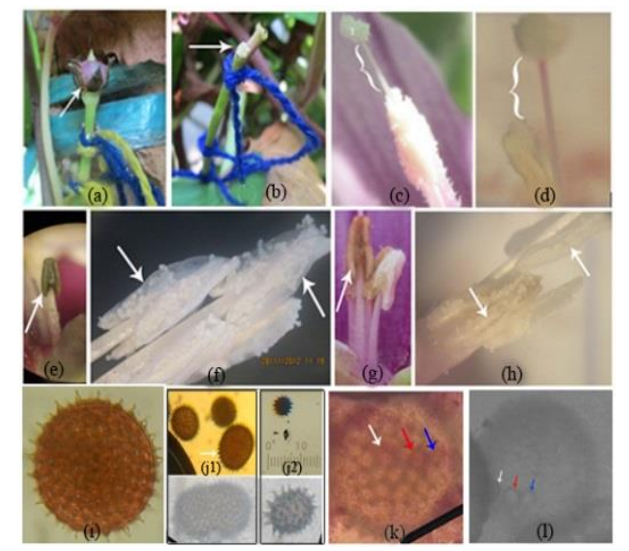

Figure 1. Sweetpotato's flower and pollen morphology. a) compatible crosses fruits, b) flower that fallen in incompatible crosses, c) and d) anther-stigma distance, e) and g) indehiscent anther were not developed, f) and h) opened anther, the MSU 03028-10 and Papua Solosa, i) circular pollen of sweetpotato, j1) and j2) very large and very small pollen, k) and l) trinucleate pollen of Papua Solosa and MSU 03028-10.

Based on pistil receptivity and anther dehiscence, both varieties showed $100 \%$ pistil receptivity and $80-100 \%$ anther dehiscence. Papua solosa showed 94, 7\% anther dehiscence (Figure 1h) and MSU 03028-10 showed (Figure 1f) 87, $3 \%$ anther dehiscence. Therefore, anther dehiscence of MSU 03028-10 was lower than Papua solosa. One of anthers was not developed (Figure 1e). Papua solosa also showed few indehiscent anthers (Figure 1g). Anthers that were ope- ned during three hours of anthesis would be wilted $[3,7]$, thus anther dehiscence was one of important factors that determine the success rate of cross.

Pollen nuclei of both varieties were trinucleated type (3 nuclei) (Figure $1 \mathrm{k}$ and $1 \mathrm{l}$ ) as Williams and Cope (1967) discovered that mature pollen in several species of genus Ipomoea were trinucletaed. Trinucleate pollen related to the sporophytic self-incompatibility with inhibition 
site of pollen germination in early tube growth. Circular pollen with normal size $(119-153 \mu \mathrm{m})$ (Figure 1i) was compatible pollen and viable pollen to be applied in compatible crosses. Abnormal pollen can be very small $(68 \mu \mathrm{m})$ (Figure $1 \mathrm{j} 2)$ or very big $(187 \mu \mathrm{m})$ (Figure $1 \mathrm{j} 1)$. Formation of abnormal pollen may inhibit fertilization in the nature. Abnormal pollen suspected as the result of abnormal cleavage. Nondisjunction and other abnormalities can occur in high percentage as a result of genetic imbalance [3]. Hexaploid chromosomes of sweet potato were suspected to cause genetic imbalance in segregation, thus leavage produced bigger and/or smaller pollen than normal pollen. Papua solosa varieties showed lower pollen viability although percentage of dehiscent anther was higher than MSU 03028-10. The lower pollen viability showed that opened anther did not determine pollen viability. The lower pollen viability affected by normal but unviable pollen (Figure $2 \mathrm{c}, 2 \mathrm{~d}, 2 \mathrm{f}$, and 2g) and abnormal pollen. Investigation of in vitro pollen germination of viable pollen had been failed. Several medium of pollen germination showed that cell substance were lysed out and didn't produce pollen tube (Figure 2i1-2i4). The success growth of pollen was only found on Bhojwani and Bhatnagar solid medium (Figure $2 \mathrm{~h}$ ).

The failure of in vitro pollen germination caused by unmatched medium or none of essential substance in the medium can support in vitro germination of trinucleate pollen of sweet potato. Brewbaker (1957) stated that trinucleate pollen was rarely germinated. Heslop-Harrison and Shivanna (1977) said that trinucleate pollen was not ready to germinate in vitro. Jones (1980) assumed that pollen viability and storage of sweet potato was not much known because none of them can be germinated in vitro. In vitro studies showed that $80-85 \%$ pollen may viable Jones 1980). Investigation on flower biology showed that one barrier that might exist in sweet potato was the incompatibility system since all of flowers component supported fertilization.

Treatment of various concentration of sucrose on stigma affected the increase of successful crosses (Table 1). Treatment in $50 \mathrm{ppm}$ concentration increased the fruit formed of Papua Solosa, MSU 03028-10, and Papua Solosa $><$ MSU 03028-10 crosses from 0\% (prelimnary test) to $70 \%, 0 \%$ to $60 \%$, and $10 \%$ to $90 \%$.
Control treatment also increased the fruit formed of Papua Solosa, MSU 03028-10, and Papua Solosa $><$ MSU 03028-10 crosses from $0 \%$ (preliminary test) to $50 \%, 0 \%$ to $40 \%$, and $10 \%$ to $70 \%$.

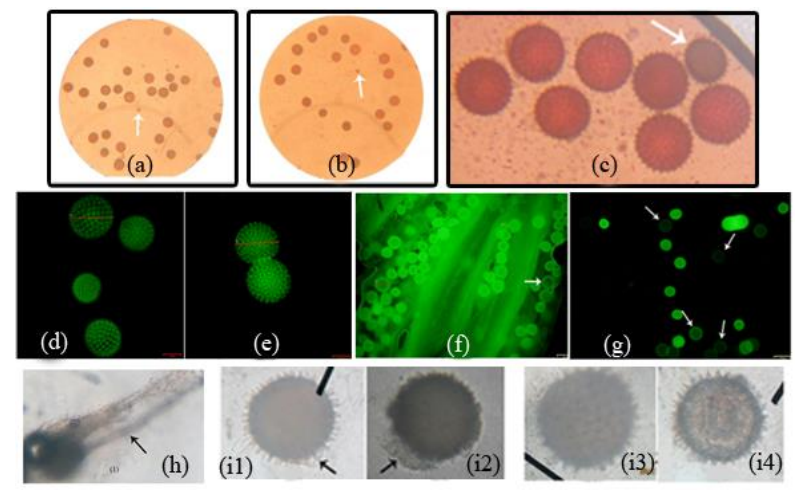

Figure 2. Pollen viability of sweetpotato. a) and d) pollen varieties Papua Solosa, b) and e) pollen MSU 03028-20, c), f) and g) viable and not viable pollen (designated arrows), h) pollen germination, i1 and i2 ) pollen on the medium Bhojwani and Bhatnagar solid and liquid, i3) pollen on the modified medium Bhojwani and Bhatnagar, i4) pollen on MS medium. a, b, c: acetocarmine staining method, $d, \quad e, f, g$ : fluorescence method, h, i1-4: methods of germination in vitro.

The increase of successful crosses assumed as the effect of stigma excision and giving $100 \mathrm{ppm}$ of 2,4D in lanolin. Concentration $100 \mathrm{ppm}$ and 150 ppm showed decreased successful crosses since there was no fruit produced in control treatment. Decreased succeed crosses might be caused by osmotic pressure on stigma. Measurement of sucrose concentration in pistil was conducted to discover the function of sucrose as an essential element that needed in pollination related with incompatibility of sweet potato. It is known that sucrose con-centration in compatible crosses (80926,2 ppm) was lower than incompatible crosses (180055 ppm).

Regression analysis was used to obtain which sucrose concentration give maximum results to increase succeed crosses. Concentration of 55, $5893 \mathrm{ppm}$ with $\mathrm{R}$ value $=0,647$ and regression line equation $\mathrm{y}=51,556+0,22 \mathrm{x}-0,003 \times 2$. was expected to produce maxi-mum successful crosses in the next breeding. Trinucleate pollen and sucrose treatment affected the incompatibility of sweet potato.

Incompatible crosses before sucrose treatment showed abnormal germinated pollen 
on stigma (Figure 3f) as the result of incompatibility mechanism. Compatible crosses showed normal pollen tube (Figure $3 \mathrm{~g}$ and $3 \mathrm{~h}$ ). Incompatibility reaction happened on the surface of stigma of early development of pollen tube after fertilization. This arrested pollen tube growth; thus no seed formed. In short, sucrose is an essential element to obtain successful pollen germination and in vivo growth [2].

Physiological action from alleles which are related to the incompatibility system maybe mediated by simple mechanism of pollen sucrose uptake [2]. Trinucleate pollen is lack of sucrose or relative small amount of certain metabolite that occur in maturity of second mitosis cleavage in late microsporogenesis. The limited sucrose inhibits pollen germination. Sporophytic selfincompatibility influenced by trinucleate pollen and site of inhibition of the pollen that occurs in early pollen growth. Sucrose helps trinucleate pollen to germinate on stigma. Sucrose in medium functioned to control osmotic pressure and served as substrate for respiration since respiration was an absolute need for pollen tube growth [1].

Table 1. Average Percentage Result of Fertilization on Sweet Potato Crosses

\begin{tabular}{cccc}
\hline Treatment & P.Solosa $><$ P.Solosa & P.Solosa $><$ MSU $03028-10$ & MSU 03028-10 $><$ MSU 03028-10 \\
S3 & $13,3 \mathrm{a}$ & $40 \mathrm{a}$ & $16,7 \mathrm{a}$ \\
S2 & $30 \mathrm{ab}$ & $46,7 \mathrm{a}$ & $23,3 \mathrm{a}$ \\
S0 & $40 \mathrm{~b}$ & $66,7 \mathrm{ab}$ & $36,6 \mathrm{ab}$ \\
S1 & $60 \mathrm{~b}$ & $86,7 \mathrm{~b}$ & $53,3 \mathrm{~b}$ \\
\hline
\end{tabular}

Note: number followed by the same letter in treatment and observation of the same parameters showed insignificant differences at $5 \% \mathrm{BNJ}$.

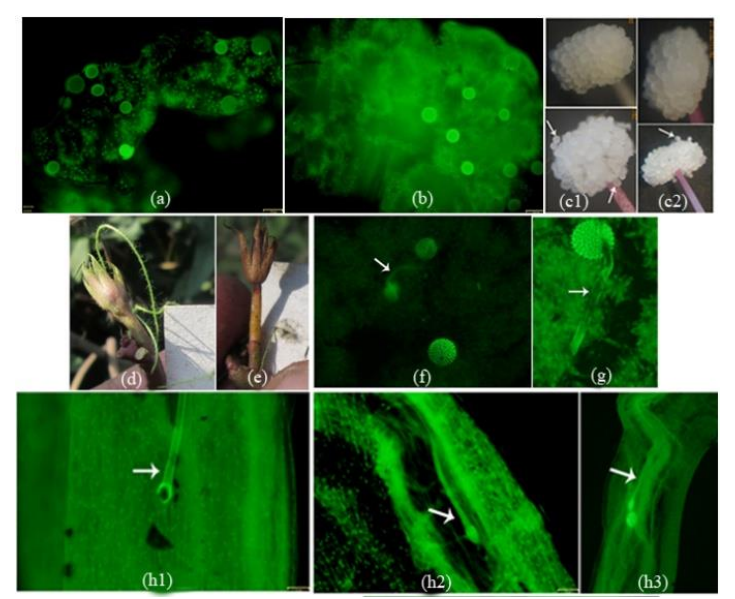

Figure 3. Pistil receptivity and pollen tubes of sweetpotato. a) and b) the receptive pistils (fluorescence), c1) and c2 stig ma was receptive when anthesis occurred, MSU 03028-10 and Papua Solosa, occured, d) and e) fruit formed and not formed after 2 weeks of compatible and incompatible crosses , f) abnormal pollen tube, g) pollen tube germinated on the stigma, h1), h2), and h3) pollen tube on the stylus.

In this research despite of sucrose treatment, excised stigma, and $100 \mathrm{ppm}$ of 2,4D in lanolin also had important effect. Williams and Cope (1967) research on excised stigma proved that fruit were increased but seeds were not completely formed because of the fallen flower. Excised stigma made it possible to eliminate the site of inhibition, thus pollen can be germinated. Regulation of inhibition system was shown by the fallen of flower in incompatible crosses. Treatment of $100 \mathrm{ppm}$ of 2,4D in lanolin at pedi- cel was used to maintain the flower after pollination in compatible and incompatible crosses. The flower did not fall after 2 weeks although no fruit formed (Figure 3e). Combination of this treatment, i.e. sucrose treatment on stigma, excised stigma, and $100 \mathrm{ppm}$ of 2, 4D in lanolin on pedicel can increase successful fertilization.

Sporophytic self-incompatibility occurs in trinucleate species and site of inhibition occurs in early pollen tube growth, whereas gametophytic self-incompatibility occurs in binucleate species 
and site of inhibition occurs in pollen tube growth [2]. Inhibition of germination is caused by differences of available metabolite of each pollen type in anthesis stage and incompatibility mechanism which limits the metabolism and sucrose uptake of male gametes $[2,3,5,10]$. Both varieties have trinucleate pollen and related to the sporophytic incompatibility. This research did not consider $\mathrm{F} 1$ offspring as a result of experimental crosses, but only focused on the increased successful crosses from lower rate to the higher rate as the effect of relationship of sweet potato's sporophytic self-incompatibility and its trinucleate pollen. Suppose that F1 offspring cannot germinate because of series of incompatibility mechanism, embryo culture can be conducted after fertilization occurred.

\section{CONCLUSIONS}

Papua solosa varieties and MSU 03028-10 has trinucleate, viable, and compatible pollen, circular shaped, and $119-153 \mu \mathrm{m}$ in size. Incompatibility system in Papua solosa varieties and MSU 0302810 are sporophytic self incompa-tibility where the inhibition occurs on stigma. Sucrose treatment can increase succeed crosses. $50 \mathrm{ppm}$ concentration increased success-ful crosses up to $86,7 \%$ in Papua Solosa $><$ MSU 03028-10; 60\% among Papua Solosa; and 53; 3\% in MSU 03028-10 itself. Sucrose concentration for applying maximum result is $55,5893 \mathrm{ppm}$.

\section{ACKNOWLEDGMENT}

The authors are indebted to the St.A. Rahayuningsih in ILETRI for providing the research's samples and also Biology Department Lab at State University of Malang for providing the opportunity to carry out this research.

\section{REFERENCES}

1. Bhojwani, S.S, Bhatnagar SP (1974) The Embryologi of Angiosperm.Third Revised Edition Vikas Publishing House. PVT. LTD, Delhi.

2. Brewbaker, James L (1957) Pollen Cytology and Self-incompatibility System In Plants, The Journal of Heredity, (Online), 48: 271-277, (http://www.oxfordjournals.org), accessed date 12 November 2012.
3. Charles WB, Hoskin DG, Cave PJ (1974) Overcoming Cross- and Self-Incompatibility in Ipomoea batatas (L.) Lam. and Ipomoea Trichocarpa Elliot. Journal of Horticultural Science. 49 (1): 113-121.

4. Edrtman, G (1943) An Introduction of Pollen Analysis. The Ronald Press, New York.

5. Ferrari TE., Lee SS, Wallace DH (1981) Biochemistry and Physiology of Recognition in Pollen-Stigma Interaction, Phytopathology. 71: 752.

6. Heslop-Harrison Y, Shivanna, KR (1977) The Receptive Surface of the Angiosperm Stigma Ann Bot, (Online), 41 (6): 1233-1258, (http://aob.oxfordjournals.org), accessed date 2 November 2012.

7. Jones A (1980) Sweetpotato. in: American Society of Agronomy-Crop Sciene of America. Hybrization of Crop Plants. Madison, Winconsin. pp. 645-655.

8. Kowyama Y, Kakeda K (2006) Analyses Of Molecular Genetic Mechanism Involved In The Sporophytic Self-Incompatibility Of Ipomoea, (Online),

(http://kaken.nii.ac.jp/d/p/16380005/2006/6/e n.en.html), accessed date 6 November 2012.

9. Poespodarsono S (1986) Pemuliaan Tanaman, Departemen Pendidikan dan Kebudayaan. Malang: Brawijaya University.

10. Sari KY, Kriswiyanti E, Astarini IA (2010) Uji Viabilitas dan Perkembangan Polen Buah Naga Putih (Hylocereus Undatus (Haw.) Britton dan Rose), Merah (Hylocereus Polyrhizus (Web.) Britton dan Rose) dan Super Merah (Hylocereus Costaricensis (Web.) Britton dan Rose) Setelah Penyimpanan, Jurnal Biologi. 14 (1): 39-44.

11. Topan (2002) Studi Fenologi Bunga Untuk Penentuan Masa Reseptif Kepala Putik dan Waktu Masak Fisiologis Bebih Ubijalar (Ipomoea batatas L.) Thesis published, Bogor: Bogor Agricutural Institue.

12. Williams DB,Cope FW (1967) Notes on SelfIncompatibility in the Genus Ipomoea L Proc. Int. Sym. on trop Root Crops, 1: 16-30. (Online), (http://www.istrc.org), accessed date 23 November 2012. 